\title{
Effect of Light Sources on Nanohardness, Elastic Modulus and Water Sorption of a Composite Resin
}

\author{
Cristiane de 0. Juchem, Vicente C. B. Leitune, Fabrício M. Collares, Susana M. W. Samuel \\ Laboratório de Materiais Dentários, UFRGS
}

\begin{abstract}
The aim of this study was to evaluate the effect of a light source on nanohardness, elastic modulus, water sorption and solubility of a composite resin. Four curing units were used, three of which had an LED and another had a halogen source. The resin composite Z250 (3M ESPE) was used for all tests. For water sorption and solubility, five resin disks were made (15 mm in diameter and $1 \mathrm{~mm}$ thick), and these were polymerized for 20 seconds at nine different points ( 1 in the center and 8 around). For nanohardness and elastic modulus evaluation, 20 cylinders ( 5 for each group) were made with a bipartite steel matrix ( $6.0 \mathrm{~mm}$ diameter and $4.0 \mathrm{~mm}$ thick). The results of this study showed that the group polymerized with the Radii light-curing unit presented less water sorption than other curing units $(\mathrm{p}<0.05)$. No statistical difference between units was found in nanohardness in $1 \mathrm{~mm}$-thick specimens. However, decreased nanohardness was shown at higher resin composite depth $(\mathrm{p}<0.05)$. A Pearson correlation showed a strong positive relationship between nanohardness and elastic modulus for all groups and depths. The light source affects the water sorption, nanohardness and elastic modulus of composite resins.
\end{abstract}

Keywords: Composite resin, polymerization, light-curing unit, nanohardness, elastic modulus.

\section{Efeito da Fonte de Luz na Nanodureza, Módulo de Elasticidade e Sorção de uma Resina Composta}

Resumo: Este estudo visa a avaliar o efeito da fonte de luz na nanodureza, módulo de elasticidade, sorção de água e solubilidade de uma resina composta. Quatro unidades fotoativadoras foram utilizadas, três LED e uma halógnena. A resina composta foi utilizada para todos os testes. Para sorção de água e solubilidade, cinco discos de resina foram produzidos (15 mm em diâmetro e $1 \mathrm{~mm}$ em espessura), e foram polimerizados por 20 segundos em nove pontos diferentes ( 1 no centro e 8 ao redor). Para a avaliação de nanodureza e módulo de elasticidade, 20 cilindros ( 5 para cada grupo) foram confeccionados com uma matriz de aço bipartida (6,0 mm de diâmetro e 4,0 mm de espessura). Os resultados do estudo mostraram que o grupo polimerizado com a unidade fotoativadora Radii apresentou menor sorção de água que as outras unidades $(\mathrm{p}<0,05)$. Nenhuma diferença estatística foi encontrada entre as unidades para nanodureza nos espécimes de $1 \mathrm{~mm}$ de espessura. Entretanto, com um aumento da profundidade uma diminuição da nanodureza foi demonstrada ( $<<0,05)$. Uma correlação positiva e forte foi demonstrada entre o modulo de elasticidade e a nanodureza para todos os grupos e profundidades. A fonte de luz influencia na sorção de água, nanodureza e módulo de elasticidade de resinas compostas.

Palavras-chave: Resina composta, polimerização, unidade fotoativadora, nanodureza, módulo de elasticidade.

\section{Introduction}

Visible light-cured composite resins are widely used in restorative dentistry ${ }^{[1]}$, and quartz-tungsten-halogen (QTH) lamp light-curing units have become the most popular method of curing dental composites in the clinical setting ${ }^{[2]}$; however, the light intensity of QTH lamps decreases over time due to bulb and filter aging $^{[2]}$ and because the heat produced by halogen lamps degrades the filter and other components. Currently, high intensity lightemitting diodes (LED) units are available. These are less energyconsuming than halogen lamps and need no external cooling ${ }^{[1,3,4]}$, providing important advantages over the QTH lamps.

Photo-curing dental composites are basically composed of organic matrix, inorganic filler, coupling agents and photo initiators. The most common initiator, camphorquinone (CQ), is activated by light in the wavelength range of 450-470 $\mathrm{nm}$, which corresponds to visible blue light. Photoactivation of the resin composite has been done with halogen lamps since the 1980s. However, in recent years, alternatives to halogen lamp have appeared, including blue light-emitting diodes (LEDs) ${ }^{[3]}$. The peak of absorption of CQ, at $468 \mathrm{~nm}$, is the same wavelength as the emission of LED units. Lightemitting diodes are semiconductors that liberate photons when electricity passes by them. Hence, LED sources generate less heat than conventional sources, because more energy is transformed into luminous energy than in light generation by incandescence. Each LED has a working lifetime of over 10,000 hours, while halogen bulbs have a limited effective lifetime of about 40-100 hours ${ }^{[4]}$.
The degree of conversion of monomer to polymer in the resin composite has an important effect on the clinical effectiveness of restoration, because proprieties like biocompatibility, dimensional stability and wear resistance increase and water sorption and solubility decrease when the degree of conversion is enhanced ${ }^{[5]}$. Restoration materials can be dissolved in the oral environment, leaching soluble component, discoloring and degrading the composite resin bulk ${ }^{[5]}$, and consequently limiting its durability. Superficial microhardness tests are an indirect method of determining the degree of conversion ${ }^{[6]}$. Already, nanohardness tests allow the evaluation of other proprieties like elastic modulus ${ }^{[7]}$. This propriety is important for evaluating the tension of union tooth/ restoration $^{[8]}$, because a high elastic modulus decreases the flow capacity of material, causing interfacial stress ${ }^{[9]}$. The aim of this study is to evaluate a composite polymerized by LED to examine its water sorption, solubility, nanohardness and elastic modulus values.

\section{Experimental}

\section{Materials}

Four curing units (one QTH and three LED) were used to test water sorption, solubility, nanohardness and elastic modulus determination of a composite resin. Units, manufacturers and characteristics are shown in Table 1. The irradiance of each curing 
Table 1. Light Curing Units (LCU) characteristics.

\begin{tabular}{ccccc}
\hline LCU & Ligth source & Ligth guide tip & Irradiance $\left(\mathbf{m W} \cdot \mathbf{c m}^{-2}\right)$ & Manufacturer \\
\hline XL-2500 & QTH & Conventional $8 \mathrm{~mm}$ & 600 & 3M ESPE, St Paul, USA \\
Elipar Free Ligth 2 & LED & Conventional $8 \mathrm{~mm}$ & 920 & 3M ESPE, St Paul, USA \\
Radii & LED & No & 1400 & SDI Limited, Bayswater, Australia \\
L.E. Demetron & LED & Conventional $8 \mathrm{~mm}$ & 950 & Demetron Research, Danbury, USA \\
\hline
\end{tabular}

unit was measured with a radiometric device (Demetron for QTH and Demetron L.E.D. for LED, Kerr Corp.). The micro hybrid resin composite Z250 (3M ESPE, St. Paul, MN, USA), color A3, was used.

\section{Water sorption and solubility}

Water sorption and solubility tests were performed in compliance with ISO 4049:2000. Five resin disks were made in a steel matrix ( $15 \mathrm{~mm}$ in diameter and $1 \mathrm{~mm}$ thick). The matrix was put directly onto a glass slide and then filled in a single increment. An acetate strip was placed on top of the matrix and then covered by a glass slide to drain the material. The glass slide was removed and the composite was polymerized for 20 seconds at nine different points ( 1 in the center and 8 around). The photopolymerization was repeated on the opposite face and then the disks were immediately placed in a stove at $37 \pm 1{ }^{\circ} \mathrm{C}$. Fifteen minutes after the beginning of the polymerization, the disks were removed from the matrix and finishing and polishing procedures were performed with sandpaper $\mathrm{n}^{\circ} 320$ and a felt disc.

After polishing, specimens were placed in a desiccator containing silica gel at $37{ }^{\circ} \mathrm{C}$ for five hours. Twenty-four hours later, the specimens were transferred to another desiccator at $22{ }^{\circ} \mathrm{C}$ for more 2 hours and then repeatedly weighed at 24 hours intervals in an analytical balance (Sartorius BP 2100, Goettingen, Germany) until a constant mass $\left(m_{1}\right)$ was obtained (i.e., until the mass loss of each specimen was not more than $0.1 \mathrm{mg}$ in any 24 hours period). The diameter and thickness of each disk was measured with a digital caliper to calculate the volume (V) in $\mathrm{mm}^{3}$. Thereafter, the specimens were stored in distilled water at $37^{\circ} \mathrm{C}$ for 7 days. Disks were weighed daily after being slightly dry until a constant weight was obtained $\left(m_{2}\right)$. The procedures to obtain $m_{1}$ were repeated to obtain $m_{3}$. Water sorption (WS) and solubility (SL) in micrograms per cubic millimeter were calculated using the following formulae:

$$
\begin{aligned}
& W S=\frac{m 2-m 3}{V} \\
& S L=\frac{m 1-m 3}{V}
\end{aligned}
$$

\section{Nanohardness and elastic modulus}

Twenty cylinders (five for each group) were made with a bipartite steel matrix ( $6.0 \mathrm{~mm}$ in diameter and $4.0 \mathrm{~mm}$ thick). The matrix was put directly onto a glass slide and then filled in a single increment. An acetate strip was placed on top of the matrix and then covered by a glass slide to drain the material. The glass slide was removed and the composite was photoactivated for 20 seconds. After polymerization, specimens were stored in a dark receptacle for 24 hours at room temperature. All the cylinders from the same group were fixed in a base of acrylic resin and sectioned under irrigation. The hemicylinders were finished and polished in an automatic polishing machine (Struers Abramin, Ballerup, Denmark) with sandpaper $n^{\circ}$ 400, 600, 800, 1200 for 2 minutes each; after that specimens were polished by a alumina impregnated felt.anohardness and elastic modulus tests were performed 24 hours after polymerization, using a Fischerscope System HV 100. A Berkivich (small three-sided pyramid) indenter was pressed into specimens with $250 \mathrm{mN}$ of load for 20 seconds, followed by 20 seconds of unloading. Nanohardness $(\mathrm{MPa})$ and elastic modulus $(\mathrm{GPa})$ values were obtained using the same device and indentation with intervals of $1 \mathrm{~mm}$ of depth from the top. For each millimeter in depth, 4 indentations were made $1 \mathrm{~mm}$ apart from each one and the values for each depth were obtained by taking the arithmetic mean of the 4 indentations of every line, representing 1,2 and $3 \mathrm{~mm}$ of depth.

Data were subjected to a two-way ANOVA and Tukey test for multiple comparisons at the 0.05 level of significance for nanohardness and elastic modulus, as well as a one-way ANOVA and Student-Newman-Keuls test for water sorption and solubility. A Pearson correlation analysis of the relationship between nanohardness and elastic modulus values was performed with a significance level of 0.05 .

\section{Results}

\section{Water sorption and solubility}

Water sorption and solubility means and standard deviations are shown in Table 2. All specimens are in agreement with ISO 4049:2000; however, the specimens cured by Radii unit showed statistically lower water sorption values $(\mathrm{p}<0.05)$ than the specimens cured with the others curing units.

\section{Nanohardness}

Nanohardness means and standard deviations are shown in Figure 1 . The depths are compared for each device and among the different devices. Groups XL 2500 and L. E. Demetron I showed superior nanohardness values for $1 \mathrm{~mm}$ of depth than for 2 and $3 \mathrm{~mm}$, in spite of $3 \mathrm{~mm}$ depths not showing statistically significant differences. The Elipar Free Light 2 and Radii groups showed no statistically significant differences between the depths of 1 and $2 \mathrm{~mm}$ or 2 and $3 \mathrm{~mm}$; however, values of $1 \mathrm{~mm}$ were statistically superior to those at $3 \mathrm{~mm}$.

Comparing the depth of polymerization among the different light curing units, no statistically significant difference was observed among the nanohardness values at of $1 \mathrm{~mm}$ depth. Nonetheless, the Radii and L. E. Demetron I groups obtained statistically higher values than did the XL 2500 group at $2 \mathrm{~mm}$. At $3 \mathrm{~mm}$, no significant difference was found among the LEDs, even though the Radii group showed different values than the XL 2500 group.

\section{Elastic modulus}

Elastic modulus means and standard deviations are shown in Figure 2. The values were compared among the depths and lightcuring units.

Groups XL 2500, Elipar Free Light 2 and L. E. Demetron I presented statistically higher values for $1 \mathrm{~mm}$ of depth than for $2 \mathrm{~mm}$ and both, higher than $3 \mathrm{~mm}$. No statistical difference was shown in the Radii group between 1 and $2 \mathrm{~mm}$ of depth, but both of these values were higher than those for $3 \mathrm{~mm}$. 
Table 2. Mean and standard deviation of Water Sorption (WS) and Solubility (SL) after the polymerization of Z250.

\begin{tabular}{ccc}
\hline Groups & WS $\left(\boldsymbol{\mu g} . \mathbf{m m}^{-3}\right)$ & SL $\left(\boldsymbol{\mu g} . \mathbf{m m}^{-3}\right)$ \\
\hline XL 2500 & $19.70( \pm 0.81) \mathrm{b}$ & $0.86( \pm 0.32) \mathrm{a}$ \\
Elipar Free Ligth 2 & $19.44( \pm 0.52) \mathrm{b}$ & $1.16( \pm 0.14) \mathrm{a}$ \\
Radii & $17.70( \pm 1.22) \mathrm{a}$ & $1.09( \pm 0.23) \mathrm{a}$ \\
L. E. Demetron I & $19.80( \pm 1.47) \mathrm{b}$ & $1.17( \pm 0.24) \mathrm{a}$ \\
\hline
\end{tabular}

Different letters in the same column shows statistical difference $(\mathrm{p}<0.05)$.

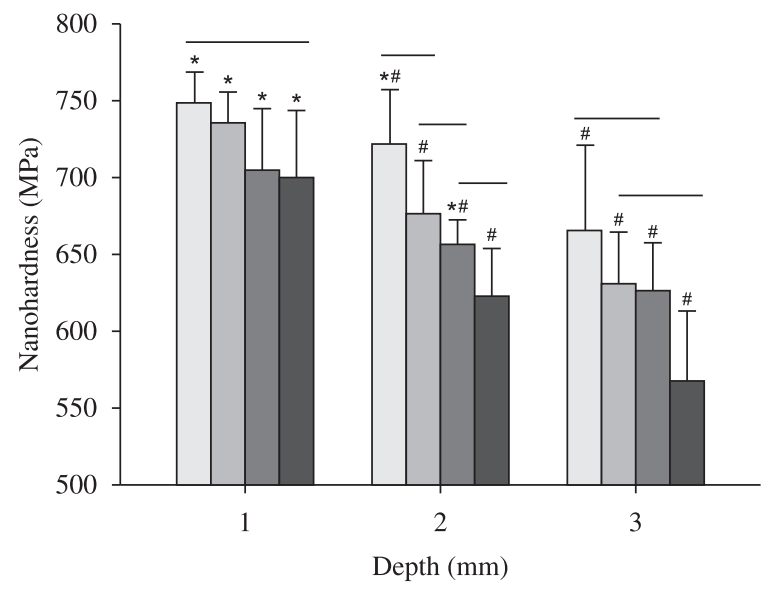

$\square$ Radii $\square$ L.E. Demetron $\square$ Elipar free ligth $\square$ XL 2500

Figure 1. Nanohardness (MPa) as a function of depth (mm) of Z250 after polymerization with different photoactivators. Light-curing units for which the nanohardness was not significantly different are connected by a horizontal line at the same depth. Different symbols show statistical difference in the same curing unit for different depths $(\mathrm{p}<0.05)$.

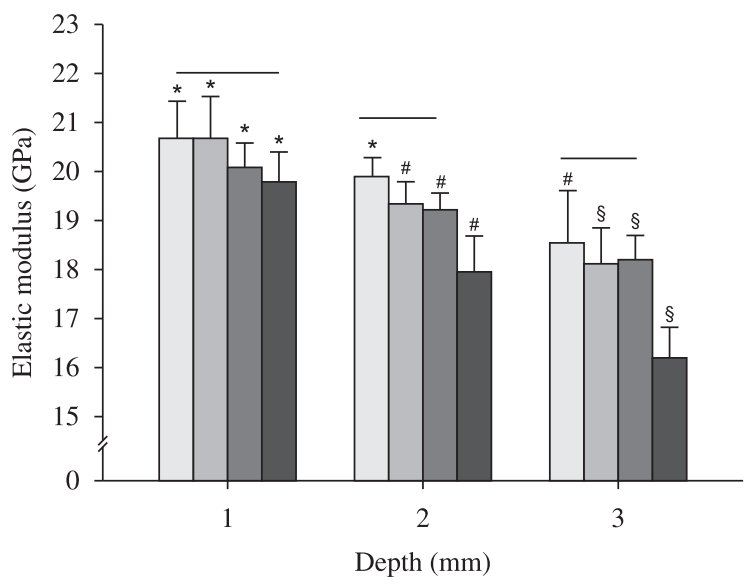

$\square$ Radii $\square$ L.E. Demetron $\square$ Elipar free ligth $\square$ XL 2500

Figure 2. Elastic Modulus (GPa) as a function of depth $(\mathrm{mm})$ of $\mathrm{Z} 250$ after polymerization with different photoactivators. Light-curing units for which the elastic modulus was not significantly different are connected by a horizontal line at the same depth. Different symbols show statistical difference in the same curing unit in different depths $(\mathrm{p}<0.05)$.

When the different light-curing units were compared, there was no statistically significant difference at a depth of $1 \mathrm{~mm}$. For the depths of 2 and $3 \mathrm{~mm}$, the XL 2500 group showed statistically lower elastic modulus values than the other groups. The Pearson correlation coefficient was used to evaluate the correlation between nanohardness and elastic modulus values. In all combinations of groups and depth are positive and strong, $\mathrm{r}^{2}>0.80(\mathrm{p}<0.01)$.

\section{Discussion}

There are many aspects involved in the polymerization process, such as material composition, type and concentration of the photo initiator, wavelength and intensity of the light source, and irradiance time. Many of the contemporary composite and adhesive systems used in dentistry that contain dimethacrylate resins are cured by irradiation with visible light. The composition of these photopolymerizable materials is generally a mixture of poly-functional methacrylate monomers ${ }^{[10]}$. The tertiary amine/camphorquinone (CQ) complex is the most widely used photosensitizer for visible-light-cured dental composite resins ${ }^{[1]}$. The absorption spectra of $\mathrm{CQ}$, ranging from $450 \mathrm{~nm}$ to a maximum of about $490 \mathrm{~nm}^{[10]}$, fit perfectly with the peak of light emitted by a blue LED. On the other hand, QTH lamps emit a large spectrum of radiation $(370-515 \mathrm{~nm})$, requiring filters to select blue light radiation. Among photoactivator units, the LED is an alternative to conventional curing units because it presents an enhanced working lifetime, eliminates the need for filters, and generates less heat and noise ${ }^{[1]}$.

A high degree of polymerization of the resin composite may lead to superior physical and mechanical properties ${ }^{[11]}$. Microhardness values are strongly related to the degree of conversion of the resin composite, as previous studies have shown ${ }^{[12]}$. A high degree of polymerization increases the cross-link density of formed polymers $^{[2,13]}$ leading to a composite restoration with enhanced mechanical and physical properties less prone to degradation.

High water sorption values and solubility of the post-polymerized resin composite can be associated with inadequate polymerization, which reduces the material properties and biocompatibility ${ }^{[14]}$. Unreacted components within the resin composite can react with solvents in the oral environment (i.e., saliva, water, soft drinks). These solvent molecules force polymer chain expansion, decreasing the internal forces and leading to polymer degradation ${ }^{[15]}$. In our tests, resin disks cured by the Radii light source showed less water sorption than those treated with other curing units $(\mathrm{P}<0.05)$, indicating an increase in stability of the composite resin restorations. Furthermore, increased water sorption of a composite restoration could be harmful to the color stability of the restoration, leading to early aesthetic failure. The solubility of dental composites reflects the amount of unreacted monomers and other low-weight molecules such as filler particle compounds and photoinitiators that have been leached into the water ${ }^{[14]}$. The elution of unreacted components could result in diffusion through dentinal tubules, causing cytotoxic effects on pulp cells ${ }^{[16]}$. Moreover, restorative procedures with more sorptive materials could lead to decreased treatment longevity.

One of the most frequently used indirect methods for verifying the degree of conversion of resin composite polymerization is the hardness test ${ }^{[17]}$. The nano-indentation technique has several advantages for hardness determination over conventional microhardness methods and offers a broader range of applications, since information on hardness as well as on the elastic modulus of a material can be obtained ${ }^{[18]}$. Analysis of the nanohardness results from our trials shows that with a $1 \mathrm{~mm}$ depth indentation specimens presented no statistical differences among the photo-curing units. However, at deeper indentations at resin composite, increased nanohardness values were shown $(\mathrm{p}<0.05)$ (Figure 1$)$. The use of clinical increments with more than 2 or $2.5 \mathrm{~mm}$ should be avoided to achieve a less degradable polymer.

Elastic modulus has an important role during stress generation caused by polymerization shrinkage. Stress generation is a parameter for the clinical performance of restorations ${ }^{[19]}$. Since stress is the product of elastic modulus and strain, a high volumetric shrinkage combined with a high elastic modulus generates a higher stress of polymerization ${ }^{[19]}$, increasing marginal failures ${ }^{[20]}$, color 
changes $^{[21,22]}$ and cuspal deflection ${ }^{[23]}$. Therefore, a restorative material should present an elastic modulus similar to dentin $(19 \mathrm{GPa})^{[18]}$ and a low shrinkage of polymerization. A high volume of organic matrix or inadequate polymerization could promote a low elastic modulus, although compromising other properties of the material. In this study, a Pearson correlation showed a positive relationship between nanohardness and eleastic modulus These results show that the source with less light intensity $\left(600 \mathrm{~mW} . \mathrm{cm}^{-2}\right)$ led to lower elastic modulus values at 2 and $3 \mathrm{~mm}$ of depth. This can be explained because higher light intensities produce enhanced physical and mechanical properties for dental composite resins ${ }^{[24]}$ and this difference appears at increased depths.

The luminous intensities were different for each light-curing unit tested in this study. The halogen lamp was used as a control group for polymerization. Analyzing the results for elastic modulus values, it is notable that there was a significant difference between the halogen unit (i.e., XL2500 with $600 \mathrm{~mW} . \mathrm{cm}^{-2}$ ) and the other curing units at depths of 2 and $3 \mathrm{~mm}$. The increased distance between the resin composite and the light source coupled with light attenuation caused by reflection, scattering and absorption of light reduces the energy absorbed by the resin composite ${ }^{[25]}$. The degree of conversion of composite resins increased with higher levels of irradiant energy. Initial free radical generation of dimethacrylate monomers is directly related to the irradiance absorbed by the composite. The rate of polymerization of resin composites is proportional to the square root of absorbed light intensity and photo-initiator concentration, as shown elsewhere ${ }^{[26]}$ and a high rate of polymerization could lead to high nanohardness and low water sorption and solubility. However, a high rate of polimerization could also lead to a high elastic modulus, which could increase restoration marginal gap, given that high polymerization shrinkage is related to high light intensity ${ }^{[27]}$.

\section{Conclusion}

Light source influences the water sorption, nanohardness values and elastic modulus of the resin composite restoration.

\section{References}

1. Campregher, U. B.; Samuel, S. M.; Fortes, C. B.; Medina, A. D.; Collares, F. M. \& Ogliari, F. A. - J. Contemp. Dent. Pract., 8, p.35 (2007).

2. Ferracane, J. L. - Dent. Mater., 22, p.211 (2006).

3. Yoon, T. H.; Lee, Y. K.; Lim, B. S. \& Kim, C. W. - J. Oral Rehabil., 29, p.1165 (2002).
4. Rueggeberg, F. A. \& Craig, R. G. - J. Dent. Res., 67, p.932 (1988).

5. Tarle, Z.; Meniga, A.; Knezevic, A.; Sutalo, J.; Ristic, M. \& Pichler, G. - J. Oral Rehabil., 29, p.662 (2002).

6. Nomoto, R.; McCabe, J. F. \& Hirano, S. - Oper. Dent., 29, p.287 (2004).

7. Tsai, P. C.; Meyers, I. A. \& Walsh, L. J. - Dent. Mater., 20, p.364 (2004).

8. Yap, A. U.; Lee, H. K. \& Sabapathy, R. - Dent. Mater., 16, p.172 (2000).

9. Toledano, M.; Osorio, R.; Osorio, E.; Fuentes, V.; Prati, C.; Garci \& Godoy, F. - J. Dent., 31, p.43 (2003).

10. Chung, K. H. - J. Dent. Res., 69, p.852 (1990).

11. Silikas, N.; Eliades, G. \& Watts, D. C. - Dent. Mater., 16, p.292 (2000).

12. Caughman, W. F. \& Rueggeberg, F. A. - Oper. Dent., 27, p.636 (2002).

13. Tay, F. R. \& Pashley, D. H. - Dent. Mater., 17, p.296 (2001).

14. Archegas, L. R.; Caldas, D. B.; Rached, R. N.; Vieira, S. \& Souza; E. M. - J. Contemp. Dent. Pract., 9, p.73 (2008).

15. Ferracane, J. L.; Berge, H. X. \& Condon, J. R. - J. Biomed. Mater. Res., 42, p.465 (1998).

16. Mantellini, M. G.; Botero, T. M.; Yaman, P.; Dennison, J. B.; Hanks, C. T. \& Nor, J. E. - J. Dent. Res., 82, p.592 (2003).

17. Ferracane, J. L. - Dent. Mater., 1, p.11 (1985).

18. Van Meerbeek, B.; Willems, G.; Celis, J. P.; Roos, J. R.; Braem, M.; Lambrechts, P. \& Vanherle, G. - J. Dent. Res., 72, p.1434 (1993).

19. Ferracane, J. L. - Oper. Dent., 33, p.247 (2008).

20. Sakaguchi, R. L. \& Berge, H. X. - J. Dent., 26, p.695 (1998).

21. Tak, O.; Altintas, S. H.; Ozturk, N. \& Usumez, A. - Clin. Oral Investig., 13, p.29 (2009)

22. Drummond, J. L. - J. Dent. Res. 87, p.710 (2008).

23. Gonzalez-Lopez, S.; Vilchez Diaz, M. A.; Haro-Gasquet, F.; Ceballos, L. \& Haro-Munoz, C. - J. Adhes. Dent., 9, p.11 (2007).

24. Ye, Q.; Wang, Y.; Williams, K. and Spencer, P. - J. Biomed. Mater. Res. B. Appl. Biomater., 80, p.440 (2007).

25. Jong, L. C.; Opdam, N. J.; Bronkhorst, E. M.; Roeters, J. J.; Wolke, J. G. \& Geitenbeek, B. - J. Dent., 35, p.513 (2007).

26. Watts, D. C. - Dent. Mater., 21, p.27 (2005).

27. Kwon, Y. H.; Kang, S. I.; Hur, B.; Park, J. K. \& Kim, H. I. - J. Biomed. Mater. Res. B. Appl. Biomater., 78, p.253 (2006).

Enviado: 25/03/10

Reenviado: 26/08/10

Aceito: $30 / 08 / 10$

DOI: 10.1590/S0104-14282011005000031 